\title{
Active and interactive teaching based on exploring forefront topics in information optics
}

Yuhong Wan, Shiquan Tao, Zhuqing Jiang, Dayong Wang, Yunxin Wang

Yuhong Wan, Shiquan Tao, Zhuqing Jiang, Dayong Wang, Yunxin Wang, "Active and interactive teaching based on exploring forefront topics in information optics," Proc. SPIE 9666, 11th Education and Training in Optics and Photonics Conference, 96660L (5 June 2009); doi: 10.1117/12.2207965

SPIE Event: Eleventh International Topical Meeting on Education and Training in Optics and Photonics, 2009, St. Asaph, United Kingdom 


\title{
Active and Interactive Teaching Based on Exploring Forefront Topics in Information Optics
}

\author{
Yuhong Wan Shiquan Tao Zhuqing Jiang Dayong Wang Yunxin Wang \\ College of Applied Science, Beijing University of Technology, Beijing 100124 \\ E-mail:yhongw@bjut.edu.cn
}

\begin{abstract}
Information Optics (i.e. Fourier Optics) is a compulsory professional course in the teaching program for juniors in the field of applied physics at Beijing University of Technology. Various methods are applied to information optics teaching in order to obtain satisfying teaching effect. Active and interactive teaching method based on exploring forefront topics was proposed and put into practice, especially for teaching "holography and holographic technology application" section of the course in which the teaching activity was not restricted to classroom any more. A visiting to the exhibit of forefront production of holographic display was introduced as an episode in the teaching. The process of teaching was designed elaborately to an interactive activity between the teacher and students, and to stimulate students to cooperate. The teaching practice proves that the active and interactive teaching method is much favorable by students and successful in information optics teaching.
\end{abstract}

Key Words: undergraduate teaching, information optics, active and interactive teaching method

\section{INTRODUCTION}

Fourier analysis is a ubiquitous tool that has found application to diverse areas of physics and engineering ${ }^{[1]}$. Information Optics is a course that applies the Fourier analysis tool to optics for dealing with the problems of diffraction, imaging, optical data processing, and holography. And the course is also named Fourier optics popularly. Information Optics (i.e. Fourier Optics) is a compulsory professional course in the teaching program for juniors in the field of applied physics at Beijing University of Technology. The Applied Physics program at Beijing University of Technology is designed to nurture innovative talent in modern applied physics, providing students both solid theoretical grounding and training for practical scientific research skills by offering 4-year BS degree ${ }^{[2]}$. Teaching and studying of professional courses play an important role in the 
process of nurturing student's innovative talent. The course content of information Optics including necessary mathematics, linear systems theory, diffraction theory as well as the application of those theories, which are more difficult for students to understand and use freely. Therefore, it is very important to pay attention to teaching methods for stimulating students' interest in learning and help them to establish a clear physical picture.

Various methods are applied to information optics teaching in order to obtain satisfying teaching effect. Such as use PowerPoint and Matlab software to visualize teaching in classroom ${ }^{[3]}$, introduce and simplify our advanced scientific research result to the professional experiments for students ${ }^{[4]}$ and so on, Active and interactive teaching method based on exploring forefront topics is proposed and put into practice, especially for teaching "holography and holographic technology application" section of the course in which the teaching activity is not restricted to classroom any more. A visiting to the exhibit of forefront production of holographic display is introduced as an episode in the teaching. The process of teaching is designed elaborately to an interactive activity between the teacher and students, and to stimulate students to cooperate. The teaching practice proves that the active and interactive teaching method is much favorable by students and successful in information optics teaching. Active and interactive teaching method is described in the paper in details.

\section{CHARACTERISTICS OF THE COURSE CONTENT}

We focus on teaching both the basis and forefront content of information optics. The details of information optics course content are shown in Table.1. The basis mainly reflected in the teaching of theories. Through comprehensive analysis of the course content, three foundations supported the entire curriculum are determined to teach: (a) Mathematics ; (b) linear system theory, which is a combination of point between communications theory and optics; (c) scalar diffraction theory, which is the basic physical foundation, introducing Fourier analysis methods to the traditional wave optics. We believe that the three basic theories are very important for students, which help them learning to built appropriate mathematical model for a more complex optical problem, on the other hand, learning how to use spectral analysis (that is, Fourier analysis) method to deal with the problems, that is, to deal with problems in a different perspective of space and frequency domain. The students will benefit from such a broad perspective in their life-long learning.

The forefront mainly reflected in the teaching of the application of Fourier optics theories. We focus on teaching the application of information optical technology in several major fields, including: (a) the frequency characteristics of optical imaging systems; (b) optical holography; (c) spatial filtering and optical information processing. This part of contents are fresh, lively and advancing with the times, we are not limited to those materials in book, but using the latest cutting-edge research results as teaching examples. 
Table.1 Compose of Teaching Content of Information Optics

\begin{tabular}{|c|c|c|}
\hline \multicolumn{3}{|c|}{ Details of the content which is designed to teach } \\
\hline \multirow{3}{*}{$\begin{array}{l}\text { Fundamentals } \\
\text { of Information } \\
\text { Optics }\end{array}$} & Mathematics & $\begin{array}{l}\text { Step, Signum, Rectangle, Triangle, Sinc, Gaussian, } \\
\text { Circular Function; } \delta \text {-Function; Convolution; Correlation; } \\
\text { 2-D Fourier Transform }\end{array}$ \\
\hline & $\begin{array}{l}\text { Linear System } \\
\text { Theory }\end{array}$ & $\begin{array}{l}\text { Linear Shift-Invariant System; Analysis of 2-Dimensional } \\
\text { Linear Systems; Two-dimensional Sampling Theory }\end{array}$ \\
\hline & $\begin{array}{l}\text { Scalar Diffraction } \\
\text { Theory }\end{array}$ & $\begin{array}{l}\text { Mathematical description of optical wave; The Kirchhoff } \\
\text { Formulation of diffraction; Angle-Spectrum of plane wave; } \\
\text { Fresnel and Fraunhofer diffraction; Diffractive gratings }\end{array}$ \\
\hline \multirow{3}{*}{$\begin{array}{l}\text { Application of } \\
\text { Information } \\
\text { Optics }\end{array}$} & $\begin{array}{l}\text { Frequency } \\
\text { Properties of } \\
\text { Optical Imaging } \\
\text { Systems }\end{array}$ & $\begin{array}{l}\text { Phase-Transform Function of Lenses; Fourier Transform } \\
\text { Property of Lenses; Imaging Analysis of } \\
\text { Diffraction-limited Systems under Coherent and } \\
\text { incoherent Illumination ; Coherent Transfer Function; } \\
\text { Optical Transfer Function; Modulation Transfer Function }\end{array}$ \\
\hline & $\begin{array}{l}\text { Optical holography } \\
\text { and application of } \\
\text { holographic } \\
\text { technology }\end{array}$ & $\begin{array}{l}\text { the basic principles of holography; a plane hologram; } \\
\text { Fourier transform holography; volume hologram, } \\
\text { holograms with white light retrieved, applications of } \\
\text { holography }\end{array}$ \\
\hline & $\begin{array}{l}\text { Opical information } \\
\text { processing }\end{array}$ & $\begin{array}{l}\text { the basic principles of coherence filter; the simple } \\
\text { amplitude and phase filtering; applications of grating filter } \\
\text { and complex filters }\end{array}$ \\
\hline
\end{tabular}

\section{AN OVERVIEW OF TEACHING METHODS}

Students have studied calculus and physical optics which are necessary basis for this course before they start to learn "Information Optics". Most of students come from the capital city of Beijing, having active thought and sensitive to modern information technology. They have strong thirst for knowledge while they are in the more competitive employment environment. We strive to help students, through the "Information Optics" course teaching and studying, to master optical information processing basic theory and methods, technology. Through the "Information Optics" teaching activities to develop and improve the students' ability of analyzing and solving 
problems, especially ability of innovating. So that students can become more competitive among the contemporary in modern society.

For the teaching of basic theory, we focus on enabling students to master that knowledge at different level. We pay more attention that key and difficult knowledge to explain in detail in class, and require students to do more exercises, so that they can receive basic training. In order to increase the perceptions of students and to develop their ability of practice, we have also designed the classic content to demonstration experiments allowing students to participate actively in the preparation in spare time and presentation in the class.

For the teaching on application of information optical theories and technology, a large number of fresh examples are introduced. For examples, when teaching distinguished ability of grating, dense wavelength division multiplexing technology is introduced. When teaching frequency response of imaging systems, the current model of the human eye and performance evaluation of digital cameras are introduced. These new materials not only have clear physical concepts, reflect the latest developments, but have a substantial nature. Our results of original research also introduce into the teaching timely. Teaching practice shows that those materials with our original idea are very helpful for students to nurture their creative thinking and ability.

\section{ACTIVE AND IETERACTIVE TECHING AND LEARNING}

\subsection{Various forms of interactive teaching}

In accordance with the characteristics of the students and teaching content, various methods of interactive teaching are put into practice. We encourage students to participate in teaching and learning actively.

At the beginning of every lesson, there is "questions and fast answer" in order to review the learned content in last time and transition to the new content. "Questions and fast answer" is lively forms to stimulate students learn actively.

Some phenomenon of diffraction, Fourier transforms of lens, spatial filtering and other classic contents are designed as classroom demonstration experiments. Volunteers are recruited in the class. The volunteers prepare after class and implement their own demonstration experiments in class. The teacher offer proper guide and suggestion.

In order to strengthen the communication between the teaching and learning, a questionnaire survey usually be done after the teaching last for about five weeks. According to the feedback of the questionnaire, we can improve our teaching and offer different help for Individual students to develop in accordance with their personality.

Through a variety of audio-visual teaching, we give students a more comprehensive training, 
Such as introducing appropriate video of principles of holography and white display hologram in English. We especially pay more attention to link theory and practice. For the teaching of holography and its application, all students are organized to visit holographic display technology and its applications in order to increase the student's perceptual knowledge and to develop their interest in learning.

\subsection{Teaching process for the content of optical holography}

The teaching content of optical holography section consists of the basic holography theory, recording material, and application of holographic technique, which is characterized by times and advancement. The teaching is designed elaborately and implemented smoothly in the process of teaching. Major steps in the implementation of teaching process are as follows:

(1) Confirming the teaching target Students can master the basic principle and application of holography, and understand the importance position of holography in information optics. Meanwhile, students' innovation awareness, cooperation and research capability ought to be cultured and improved through the teaching and learning.

(2) Teachers' lecturing: the teacher always takes two hours to explain the basic holography theory and holography classification, which can make students grasp the correlative concept based on comprehension. The heuristic and discoverable method is applied to help students learn new knowledge.

(3) Determining the activity topic and learning groups: Some reference topics are given (as the following Table 2). Students are demanded to learn the content of holography display and application by themselves in combination with network resources, teacher's courseware and other reference materials. And every student is required to choose an interested topic to finish their term paper. Learning groups are divided according to their term paper topic and the collective research subject and sub-subject for each member are confirmed. With the exploring issues, all of students are organized to visit the internal top-ranking productions of holography display in Beijing University of Posts and Telecommunications, and some key knowledge are expounded on the visiting spot. The perceptual cognition is enhanced, which can lead them to combine the theory and practice.

(4) Active cooperation and communication: Each group needs to investigate a mass of materials including internet resources, obtain help from teachers, and discuss problems together in their spare time, and finally fulfill the learning products. The potential latent of students is inspired by this kind of teaching and learning process. 
(5) Showing learning production by Oral Presentation in class: Each group elects one student to show their production by multimedia in class. So that the learning productions can be exchanged with each other. All the students will benefit more from the exchange, discussion, self-comment and mutual-evaluation. Any question or query to each study production is proposed energetically, and the advantages and shortcomings are deliberated earnestly. Eventually, the excellent achievement is voted by teachers and students to express a full affirmation to the intelligent labor outcomes. Meanwhile, the attitude of active participation is also encouraged and praised adequately.

Table 2. Details of Reference Topics of Term paper and Learning Groups

\begin{tabular}{|c|c|c|c|c|c|c|c|}
\hline & Reference Topics & \multicolumn{6}{|c|}{ Student Number who select the topic } \\
\hline 1 & $\begin{array}{c}\text { The theory and development of Rainbow } \\
\text { hologram }\end{array}$ & 1113 & 1116 & 1128 & 1207 & 1228 & 1230 \\
\hline 2 & $\begin{array}{l}\text { Principles and development of holography } \\
\text { with white light retrieved }\end{array}$ & 1123 & 1111 & 1119 & 1213 & 1218 & 1208 \\
\hline 3 & Holographic anti-counterfeiting technology & 1101 & 1124 & 1107 & 1222 & 1225 & 1224 \\
\hline 4 & $\begin{array}{l}\text { Principles and status of high-density } \\
\text { large-capacity optical storage technology }\end{array}$ & 1108 & 1132 & 1118 & 1226 & 1204 & 1206 \\
\hline 5 & $\begin{array}{l}\text { Volume holographic grating devices and their } \\
\text { development }\end{array}$ & 1117 & 1106 & 1232 & 1212 & 1211 & \\
\hline 6 & $\begin{array}{c}\text { Principles and status of three-dimensional } \\
\text { holographic display and movies }\end{array}$ & 1129 & 1127 & 1103 & 1210 & 1220 & 1227 \\
\hline 7 & $\begin{array}{c}\text { The classification of holographic recording } \\
\text { material, recording mechanism, } \\
\text { characteristics and application }\end{array}$ & 1126 & 1215 & 1223 & 1202 & & \\
\hline 8 & $\begin{array}{l}\text { Application of digital holography in the } \\
\text { biological cells imaging }\end{array}$ & 2127 & 113 & 1121 & 1214 & 1219 & 1221 \\
\hline 9 & $\begin{array}{l}\text { Application of digital holography in of } \\
\text { three-dimensional measurement }\end{array}$ & 1105 & & & & & \\
\hline 10 & $\begin{array}{c}\text { The principle of computer-generated } \\
\text { hologram and its application }\end{array}$ & 1114 & 1112 & 1209 & 1216 & & \\
\hline 11 & $\begin{array}{l}\text { principle of Dynamic synthesis hologram and } \\
\text { its development }\end{array}$ & 1115 & 1104 & 1125 & 1217 & & \\
\hline 12 & Optional subject you interested in & 1102 & & & & & \\
\hline
\end{tabular}




\section{TEACHING EFFECT AND EVALUATION OF STUDENTS}

Active and interactive teaching methods are favorable by students. They express their thought in the following words:

"This kind of teaching method enhanced the class attractiveness and accelerated my study interest". "The products about holography display widen my visual field, and made me more interested in holography technology". "Study force and enthusiasm were inspired by this kind of teaching approach". "The visit in Beijing University of Posts and Telecommunications not only increased my interest to this curriculum, but also made me learn the scientific attitude and faith". All of the aforementioned aspirations from students demonstrate the active and exploring teaching pattern has produced a favorable instructional effect.

After teaching reform and practice for several years, information Optics in our school curriculum has been formed teaching modes with its own distinct characteristics, and has achieved good teaching results. The teaching effect and learning outcomes of students are reflected in the professional design of experiments, graduate and postgraduate study. During the teaching and learning process, a certain amount of scientific training are offered which is very helpful to nurture students' ability of innovative practice. Each year, a large number of outstanding students in the field of applied physics choose to major in optics as their postgraduate study.

As far as teaching of this course in future, we will continue to strengthen and improve the innovative modes of teaching, focus on the basis while the innovative practice of the students abilities, so that students learn not only knowledge, but also improve the ability to learn methods for their life-long learning. Through our teaching activities, the basic tasks of undergraduate education can be effectively completed, namely: for students (1) making a good theory foundation and attain the ability of lifelong studying when graduating; (2) Increase the competitiveness of engage in practical work after graduation (3) to do some preparation for continuing to study as a post-graduate student.

\section{Acknowledgements}

This work is partly supported by Research Foundation for Excellent Youth of Beijing Municipal Organization Department (Contract No.Q0006111200801) and the Science Foundation of Education Commission of Beijing, China. (Contract No.KZ200910005001). 


\section{References}

1. Joseph W. Goodman, "Introduction to Fourier Optics “, Third edition, Roberts and Company Publishers, 2005.

2. Shiquan Tao, Li Wang, and Zhuqing Jiang, "Revise of the Undergraduate Program for Speciality in Applied Physics to Intensify Training in Optics and Photonics", 10th International Topical Meeting on Education \& Training in Optics and Photonics Ottawa, Ontario, Canada, 3-6 June 2007 Proceedings of the 2007 ETOP Conference; ISBN 9780819469571.

3. WAN Yuhong, TAO Shiquan, JIANG Zhuqing, WANG Dayong, WANG Li, "Enhancing teaching effect of information optics using visualized technique", Journal of Yunnan University,30(S2):90-93,2008.

4. Shiquan Tao, Dayong Wang, Zhuqing Jiang and Yuhong Wan, "Introduction of advanced optics research to laboratory-experimental course for undergraduate teaching", Conference on Education and training in optics and photonics (ETOP2005) ,France, Oct. 25-28, 2005. 